\title{
Picie kontrolowane - propozycja strategii pomocowych dla młodych dorosłych
}

\section{KEYWORDS}

alcohol dependence, controlled drinking, consumption by adolescents and young adults, causes of addiction, results of the controlled drinking study

\begin{abstract}
Dolata Dorota, Picie kontrolowane - propozycja strategii pomocowych dla młodych dorosłych [Controlled Drinking - Helping Strategy Proposal for Young Adults]. Kultura - Społeczeństwo - Edukacja nr 2(6) 2014, Poznań 2014, pp. 221-245, Adam Mickiewicz University Press. ISBN 978-83-232-2869-1. ISSN 2300-0422
\end{abstract}

As statistics in Poland show, more and more younger people reach for alcohol and, what is more, they struggle to control their drinking. This often leads to a number of serious consequences for all health, economic, psychological, and social ones. They include beatings, injuries, loss of material property or even conflict with the law. Uncontrolled chemical intoxication may even lead to the long-term consequences which is e.g. addiction to alcohol. In some countries, they apply a form of assistance to people drinking in a risky way, and not only to them, which is aimed at the acquisition of skills for controlling alcohol consumption. There are used a number of methods and progressive stages of dealing with the client, so that he or she would learn controlled drinking. Therefore, not only this article briefly presents the causes and mechanisms of addiction resulting in the wide range of consequences, but also is the proposal for a strategy of assistance for young adults focused on the acquisition of skills in controlling the use of alcohol, as well as shows the results of the effectiveness of this form of assistance in some countries in the world.

Spożywanie alkoholu przez Polaków jest tematem często pojawiającym się w dyskursie, zarówno na polu społecznym, jak i naukowym. Kwestię alkoholu oraz związanych z nim konsekwencji porusza się w z perspektywy prawnej, ekonomicznej, psychologicznej, socjologicznej czy pedagogicznej. Osoby uzależnione lub ponoszące konsekwencje uzależnienia swoich bliskich zna każdy człowiek, inaczej niż chore na raka czy z zaburzeniami psychicznymi. Alkohol jest towarzyszem i niejako „kolejnym gościem” wielu przyjęć czy spotkań towarzyskich, umacnia się i kon- 
stytuuje w danym obszarze - nie tylko tym zarezerwowanym dla osób pełnoletnich. Uwidacznia się to $\mathrm{w}$ prostym eksperymencie, kiedy prosi się dzieci przedszkolne, aby odegrały urodziny lub imieniny swoich rodziców. Następuje wówczas seria toastów oraz podnoszenie imitujących kieliszki przedmiotów. Tym bardziej nie dziwi zatem fakt nazywania alkoholizmu problemem społecznym. Dane statystyczne zebrane przez Państwową Agencję Rozwiązywania Problemów Alkoholowych wskazują, że $2 \%$ populacji uzależnione jest od alkoholu, ponadto $4 \%$ to osoby dorosłe żyjące $\mathrm{w}$ otoczeniu uzależnionego, taki sam procent stanowią dzieci wychowujące się $\mathrm{w}$ domu $\mathrm{z}$ problemem alkoholowym, a 5-7\% populacji to jednostki pijące w sposób szkodliwy ${ }^{1}$, co łącznie stanowi około $16 \%$ społeczeństwa.

Dane statyczne zebrane w Polsce w latach 1998-2009 przez Główny Urząd Statystyczny, a opracowane przez Państwową Agencję Rozwiązywania Problemów Alkoholowych, wskazują na rosnącą tendencję konsumpcji alkoholu w przeliczeniu na jednego mieszkańca kraju. W roku 1995 na jedną osobę (w przeliczeniu na stuprocentowy alkohol) przypadało 6,46 l, z kolei w roku 2008 wskaźnik ten wzrósł aż do 9,58 1. Tendencja spadkowa konsumpcji alkoholu wystąpiła jedynie w dwóch przedziałach czasowych (w latach 2001-2002 oraz w roku 2009), co wiązało się między innymi z podniesieniem akcyzy na napoje spirytusowe ${ }^{2}$. Okazuje się, że w przeciągu ostatnich dwóch dekad znacząco wzrosło spożycie piwa w Polsce. Dokładniej, „spożycie piwa w przeliczeniu na $100 \%$ alkoholu wzrosło $\mathrm{w}$ latach 1992-2011 z 2,12 litra do 5,19 litra"3.

Jak widać, istnieje duża zależność zażywania wyrobów alkoholowych od ich dostępności ekonomicznej. Wspomniana powyżej tendencja wzrostowa ilości spożywanych wyrobów spirytusowych uwarunkowana jest między innymi ich atrakcyjnością cenową w porównaniu do cen wina czy piwa. Jak wskazują dane statystyczne, w roku 1998 za średnią pensję można było kupić 56 butelek wódki, z kolei w roku 2008 już 158, czyli prawie trzy razy więcej, a piwa jedynie dwa razy więcej (w 1998 roku 504 butelki, a w 2008 roku 1094), z czego należy mieć na uwadze wyższe stężenie procentowe wódki

\footnotetext{
${ }^{1}$ Państwowa Agencja Rozwiązywania Problemów Alkoholowych, Statystyki; http://www.parpa.pl/ index.php? option=com_content\&task=view\&id=155\&Itemid=16 (dostęp: 01.04.2014 r.).

${ }^{2}$ Ibidem.

${ }^{3}$ M. Rapkiewicz Ekspertyza. Wpływ zmian wysokości stawki podatku akcyzowego od wyrobów spirytusowych w 2014 r. na dochody budżetu państwa; http://www.sobieski.org.pl/wp-content/uploads/ Akcyza_2014_Instytut_S obieskiego.pdf, s. 21 (dostęp: 22.04.2014 r.).

${ }^{4}$ Państwowa Agencja Rozwiązywania Problemów Alkoholowych, Statystyki, op. cit.
} 
Kolejnym czynnikiem wpływającym na ilość zażywanego w Polsce alkoholu jest jego fizyczna dostępność. Stale zwiększa się liczba punktów sprzedaży substancji psychoaktywnych, nierzadko promująca ich spożycie ${ }^{5}$. Często w sklepach, w których można nabyć wyroby alkoholowe, sprzedaje się je nielegalnie osobom nieletnim, co wynika między innymi z dość dużej akceptacji społecznej dla intoksykacji chemicznej młodocianych oraz z coraz większego przyzwolenia rodziców na spożywanie alkoholu przez ich wychowanków (Grzybowski, 2005: 249).

\section{Konsumpcja alkoholu przez polskich adolescentów i mlodych dorosłych}

Niepokojące są wynik badań przeprowadzone przez Krzysztofa Ostaszewskiego, Małgorzatę Cybulską, Katarzynę Kocoń, Agnieszkę Pisarską, Annę Borucką, Katarzynę Okulicz-Kozaryn oraz Krzysztofa Bobrowskiego w kilku turach na przestrzeni lat 1984-2008 w wybranych szkołach warszawskich. Według tych badaczy, zauważalna jest duża dostępność napojów alkoholowych dla młodzieży w wieku gimnazjalnym oraz licealnym. Wskazuje się również na coraz niższy przedział wiekowy jednostki w momencie pierwszego doświadczenia $\mathrm{z}$ alkoholem oraz regularność jego spożywania już w młodym wieku. Jak się okazuje, ponad połowa uczniów w wieku piętnastu lat przyznaje się do systematycznego spożywania alkoholu, a badania przeprowadzone w roku 2008 wykazały, że co szósta dziewczynka i co czwarty młodzieniec doświadczyli już stanu upojenia alkoholowego ${ }^{6}$.

Podobnie zjawisko spożywania alkoholu przez nieletnich oraz młodych dorosłych przedstawiają dane statystyczne zebrane w latach 2004-2009 przez Główny Urząd Statystyczny dotyczące liczby młodzieży spożywającej alkohol. Wskazują one, co prawda, na zmniejszający się odsetek młodych ludzi (15-19 lat) spożywających alkohol (45,3\% w roku 2004, a 42,0\% w roku 2009), podobnie z osobami dorosłymi (20-29 lat - z 83,2\% w roku 2004 na $82,2 \%$ w roku $2009^{7}$ ), jednak mimo zauważalnej tendencji spadkowej konsumpcji alkoholu wśród adolescentów, młodych dorosłych i dorosłych, cały czas prawie połowa $\mathrm{z}$ nich już w młodym wieku miała styczność ze środkami psychoaktywnymi. Nie są to satysfakcjonujące wyniki,

${ }^{5}$ Ibidem.

${ }^{6}$ K. Ostaszewski, K. Bobrowski, A. Borucka, M. Cybulska, K. Kocoń, K. Okulicz-Kozaryn, A. Pisarska, Monitorowanie zachowań ryzykownych młodzieży. Badania mokotowskie; http://www.ipin.edu.pl/ wordpress/wp-content/uploads/2010/03/Raport_Badania_Mokotowskie.pdf, s. 26 (dostęp: 18.04.2014 r.).

${ }^{7}$ Urząd Statystyczny w Krakowie, Zdrowie dzieci i młodzieży w Polsce w 2009 r.; http://www. stat.gov.pl/cps/rde/xbcr/gus/zo_zdrowie_dzieci_mlodziezy_w_polsce_2009.pdf (dostęp: 01.04.2014 r.). 
szczególnie jeśli ma się na względzie nierzadko poważne konsekwencje zdrowotne oraz społeczne wynikające ze spożywania napojów wysokoprocentowych. Przykładem konsekwencji zdrowotnych jest liczna grupa młodych osób zgłaszających się do ambulatoryjnej opieki psychiatrycznej na skutek zaburzeń wynikających z zażywania alkoholu (aż 362,6 osób na 100 tys. ludności). Również liczny odsetek stanowiły dzieci i dorastająca młodzież lecząca się w ramach psychiatrycznej opieki ambulatoryjnej na skutek zespołu uzależnienia ${ }^{8}$.

Wyniki badań na temat używania alkoholu i narkotyków (ESPAD), przeprowadzonych w szkołach przez Europejski Program Badań Ankietowych, wskazują, że najczęstszymi negatywnymi dla konsumenta i środowiska doświadczeniami oraz szkodami wynikającymi ze spożywania alkoholu były między innymi uczestniczenie w bójce, co wiązało się ze zniszczeniem cudzego mienia, a także problemy z rodzicami czy kłopoty z policją (Grzybowski, 2005: 246).

Podsumowując, można stwierdzić, że waga problemów związanych z dostępnością oraz spożyciem alkoholu wśród młodzieży jest duża. Mimo statystycznego spadku współczynnika liczby młodych osób używających substancji psychoaktywnych, wciąż niepokojąco duża grupa osób z tego przedziału wiekowego eksperymentuje z napojami wysokoprocentowymi, co niejednokrotnie niesie za sobą poważne konsekwencje zdrowotne i społeczne.

\section{Polska na tle innych krajów Europejskich}

Na tle statystyk Europejskich, w Polsce występuje mniejsze spożycie alkoholu aniżeli w wielu innych państwach. Średnia unijna poziomu konsumpcji alkoholu przypadającego na jednego mieszkańca powyżej 15 roku życia wynosi 10,85 1 100\%, z czego w Polsce wskaźnik ten wynosi 10,61 100\%. Stanowczo wyprzedzają nas takie kraje, jak Hiszpania, Niemcy czy Francja, gdzie notuje się spożycie alkoholu powyżej 10,7 $1100 \%{ }^{9}$.

\section{Przyczyny uzależnienia od alkoholu}

Problematyka zjawiska uzależnienia jest wieloaspektowa, a także niezwykle skomplikowana. Wskazują na to liczne badania empiryczne prowadzone w obrębie al-

\footnotetext{
${ }^{8}$ Ibidem, s. 68-69.

${ }^{9}$ Polski Przemysł Spirytusowy, Alkohol i społeczeństwo; http://www.pps.waw.pl/pliki/Newsletter/ Newsletter_1_2012.pdf, s. 5 (dostęp: 01.04.2014 r.).
} 
koholików trzeźwiejących oraz czynnych, a także ich rodzin. Do dzisiaj, korzystając między innymi z ich wyników, nie uzyskano jednoznacznej odpowiedzi mogącej zweryfikować przyczyny choroby alkoholowej. Wynika to ze zbytniej złożoności mechanizmów warunkujących jej powstanie, które nie zostały jeszcze dobrze poznane (Woronowicz, 2009: 62), a także niepotwierdzonej jednoznacznie wiarygodności badań nad genetycznymi uwarunkowaniami choroby alkoholowej.

Wśród wielu badaczy panuje zgodność co do trzech czynników predysponujących jednostkę do choroby alkoholowej i determinujących uzależnienie. Należy jednak wspomnieć, że wystąpienie jednego $\mathrm{z}$ tych czynników nie prowadzi bezwzględnie do rozwoju problemu alkoholowego. Każdy z nich predysponuje jednostkę do uzależnienia, jednak nie determinuje w sposób jednoznaczny choroby.

Jednym ze wspomnianych powyżej czynników przyczyniających się aż w 40$-60 \%$ do wystąpienia uzależnienia są uwarunkowania genetyczne (Szmachowiec, Kucharska-Mazur, Szmachowiec, 2011: 117). Badania przeprowadzone na bliźniętach, a dotyczące zgodności genotypu, wykazały, że wśród monozygotycznych bliźniąt płci męskiej zauważa się większą zgodność odziedziczalności wzorców picia $(60 \%)$ aniżeli w grupie męskiej bliźniąt dyzogotycznych (39\%). Podobnie w grupie bliźniąt dwujajowych i jednojajowych płci żeńskiej zauważono wyższą zgodność występowania alkoholizmu u tych z grupy bliźniąt monozygotycznych aniżeli dyzogotycznych (Cierpiałkowska, Ziarko, 2010: 122-124). Można zatem stwierdzić, że dziedziczność genetyczna ma związek z występowaniem u określonych osób problemów alkoholowych, jednak do dzisiaj nie sprecyzowano dokładnie, czy istnieje gen lub geny warunkujące chorobę oraz w jakim stopniu mają one wpływ na jej rozwój i wystąpienie.

Mówi się także o zależności pomiędzy genetyczną dziedzicznością aktywności dehydrogenaz a częstotliwością konsumpcji alkoholu. Gdy wspomniana aktywność dehydrogenazy jest wysoka, po spożyciu dużej ilości alkoholu i występującej wówczas poprawie samopoczucia jednostka odczuwa następnie niewielkie skutki spożycia w postaci tak zwanego „kaca”. Z kolei niska aktywność dehydrogenazy aldehydowej warunkuje wystąpieniem silnego „kaca”, przez co nie zachęca do konsumpcji alkoholu (Woronowicz, 2009: 65-66).

Alkohol działa także na wzrost aktywności układu opioidowego. Jak się okazuje, u osób, u których występują niedobory czynności receptorów opiatowych, alkohol pełni funkcje kompensującą (Niewiadomska, Sikorska-Głodowicz, 2004).

Badania przeprowadzone na szczurach wykazują, że nie bez znaczenia pozostaje również rola neuroprzekaźników w spożywaniu alkoholu. Jak pisze Bohdan Wo- 
ronowicz, „osobniki wykazujące niższy poziom serotoniny w mózgu i posiadające mniej neuronów serotoninergicznych szybko uzależniały się od alkoholu, natomiast te, które posiadały tych neuronów więcej, nie wykazywały zainteresowania alkoholem" (Woronowicz, 2009: 68). Niebagatelne znaczenie ma również dopamina regulująca pobudzenie energetyczne oraz regulująca nastrój (Niewiadomska, Sikorska-Głodowicz, 2004). Wykazano, że zwierzęta mające niższy poziom dopaminy w niektórych obszarach mózgu, bardziej preferowały alkohol (Niewiadomska, Sikorska-Głodowicz, 2004).

Podsumowując wątek genów, okazuje się, że pewne cechy predysponujące do zachorowania na chorobę alkoholową mogą być i są dziedziczne, jednak nie są determinantami określającymi jednoznacznie wystąpienie choroby, gdyż na to składa się wiele czynników, w tym także czynniki społeczne i psychologiczne.

Analizując przyczyny uzależnienia z punktu widzenia psychologii, można wyodrębnić cztery obszary wyjaśniające rozwój choroby alkoholowej. Na gruncie teorii uczenia się identyfikuje się alkohol jako bodziec bezwarunkowy, „skojarzony z wieloma sygnałami z otoczenia osoby je zażywającej: obrazami, dźwiękami, odczuciami, sytuacjami” (Seligman, Walker, Rosenham, 2003: 632). Zgodnie z tą teorią, bodziec bezwarunkowy ( $w$ tym wypadku alkohol) z czasem staje się bodźcem warunkowym, niezbędnym do uzyskania pozytywnych stanów emocjonalnych.

Inaczej analizują problem psychoanalitycy, których zdania się różnią. Freud uważał, że konsumpcja alkoholu wypływa z potrzeby doznania spokoju i zaprzestania odczuwania lęku. Inni z kolei twierdzą, że ludzie mają podświadome tendencje do samozniszczenia, z czego wynika uzależnienie. Jeszcze inni „dopatrują się wpływu tak zwanego konfliktu wewnętrznego między popędami zależności a bodźcami agresji” (Woronowicz, 2008: 37).

Zwolennicy modelu poznawczego inaczej wyjaśniają przyczyny uzależnień od alkoholu. Zwraca się tu uwagę na relację, jaka zachodzi pomiędzy indywidualnymi oczekiwaniami co do efektu spożycia alkoholu a częstotliwością jego konsumpcji i pejoratywnymi oczekiwaniami a powstrzymywaniem się od picia (Woronowicz, 2009: 71-72).

Dawniej mówiono o tak zwanej „osobowości uzależnieniowej”. Twierdzono, że osoby nadużywające substancji psychoaktywnych mają defekt osobowości warunkujący u nich podatność na uzależnienie i zażywanie niektórych związków chemicznych (Seligman, Walker, Rosenham, 2003). Ponadto, Robert C. Cloninger uważa, że pewne „cechy temperamentu mogą być swoistym czynnikiem ryzyka” (Jędrzejko [et al.], 2009: 91). Badania nie wykazały do końca słuszności tej koncepcji, jednak 
współcześnie wiadomo, że wyższy poziom agresji prezentowany w dzieciństwie, a także zaburzenia zachowania, w tym zachowania antyspołeczne, nierzadko mają związek z wystąpieniem choroby alkoholowej w dorosłości (Woronowicz, 2009: 70-74).

Mówi się także o związku spożywania alkoholu z niedojrzałością emocjonalną wynikającą z nieprawidłowego przebiegu procesu kształtowania się osobowości, na który wpływ mają czynniki zewnętrzne oraz wewnętrzne (predyspozycje genetyczne niezależne od jednostki). Często się zdarza, że takie osoby podczas doświadczania sytuacji trudnych sięgają po alkohol w celu ułatwienia sobie funkcjonowania oraz ucieczki od problemów w stan odprężenia i relaksu (Woronowicz, 2009: 72).

Popularna była także oparta na gruncie behawioralno-poznawczym teoria redukcji napięcia. Na podstawie tej teorii mówi się o gratyfikującej funkcji alkoholu, spełniającej rolę uśmierzającą napięcie emocjonalne i osłabiającą reakcję na stres. W myśl tej hipotezy, na skutek przyzwyczajenia organizmu do spożywania alkoholu w sytuacjach stresowych, czego konsekwencją będzie wygaszenie nieprzyjemnych stanów emocjonalnych, każde kolejne okoliczności problematyczne będą wywoływały reakcję warunkową (Kozielecki, 1995: 30-33), czyli konsumpcję alkoholu, która pozwoli zredukować napięcie emocjonalne (Woronowicz, 2009: 71). W ten sposób używanie środków psychoaktywnych staje się reakcją wyuczoną, jedyną możliwą przy wystąpieniu wysokiego napięcia psychicznego.

Niebagatelne znaczenie ma także wpływ czynników środowiskowych. Można je podzielić na determinanty kulturowe, to jest społecznie ukształtowane spojrzenie na normy i wzorce picia (przy czym Polska uważana jest za „kulturę pijacką” [Woronowicz, 2009: 69]), dostępność na rynku substancji psychoaktywnych, a także czynniki rodzinne, mające wpływ na wystąpienie i podtrzymywanie choroby alkoholowej (Woronowicz, 2009: 69).

Te ostatnie można rozumieć dwojako. $Z$ jednej strony będzie to wpływ rodziny pochodzenia na ukształtowanie wzorców picia i zachowania warunkujących możliwość popadnięcia jednostki w chorobę alkoholową. Badania pokazują, że alkoholicy najczęściej pochodzą z domów alkoholowych bądź z takich, gdzie panowała całkowita abstynencja (Woronowicz, 2009: 70). Z drugiej strony, szeroko mówi się o tak zwanych rodzinach alkoholowych w ujęciu systemowym, gdzie poprzez brak granic pomiędzy członkami rodziny - co często powoduje powstanie relacji symbiotycznych, w których nie powstają odrębne tożsamości - a jednocześnie poprzez sztywne granice obejmujące cały system i niedopuszczające wpływu czynników z zewnątrz, a także sztywne zachowania regulacyjne, choroba alkoholowa jest podtrzymywana i niezwykle trudno jest zatrzymać jej rozwój (Margasiński, 2010). 
Problematykę uzależnienia od substancji psychoaktywnej można podjąć z punktu widzenia trzech obszarów: genetycznego (i wspomnianej dziedziczności cech), psychicznego (w tym różnych koncepcji psychologicznych uzasadniających przyczyny szkodliwej konsumpcji alkoholu), a także środowiskowego (w tym analizy pierwotnego środowiska kształtującego i modelującego zachowania jednostki). Problematyka uzależnień jest niezwykle złożona, w związku z czym nie można jej interpretować z punktu widzenia jednego obszaru teoretycznego, ale należy to uczynić na gruncie wymienionych wyżej trzech aspektów, wzajemnie powiązanych, korelujących ze sobą i wspólnie determinujących rozwój choroby alkoholowej.

\section{Spoleczne konsekwencje intoksykacji chemicznej}

Jak zostało wspomniane powyżej, czynniki środowiskowe pośrednio wpływają na rozwój choroby alkoholowej. Wczesna inicjacja alkoholowa w gronie rówieśników czy w środowisku rodzinnym, gdzie rodzice dodatkowo dają przyzwolenie na próbowanie/picie alkoholu przez swoje dzieci, zwiększa ryzyko pojawienia się u nich w przyszłości potencjalnych problemów związanych ze spożywaniem alkoholu (Woronowicz, 2009: 202). Ponadto, takie przyzwalające postawy rodziców oraz wczesna intoksykacja alkoholowa są jednymi z wielu czynników zwiększających ryzyko pojawienia się zachowań problemowych u adolescenta (Ostaszewski, 2005: 122). Dodajmy, że Polska uważana jest za kraj, w którym dominuje duże przyzwolenie dla intoksykacji alkoholowej, a sama konsumpcja alkoholu jest na porządku dziennym (Woronowicz, 2009: 70-71).

Jednocześnie nadmierne spożywanie alkoholu, czyli takie, które prowadzi do stanu upojenia alkoholowego, często niesie za sobą, oprócz konsekwencji zdrowotnych, ekonomicznych czy psychologicznych, również konsekwencje społeczne. Badania przeprowadzone przez ESPAD, który w Polsce został wprowadzony pierwszy raz w 1995 roku przez badaczy z Zakładu Psychiatrii i Neurologii w Warszawie, wykazały, że co dziesiąte dziecko po spożyciu alkoholu brało udział w bójce, z kolei co dwudziesty adolescent po wypiciu alkoholu doznał szkód cielesnych, a co piętnasta nastolatka doświadczyła niepożądanych przez nią kontaktów seksualnych (Grzybowski, 2005: 245-246). Oprócz wspomnianych konsekwencji intoksykacji chemicznej, młodzież wymieniła również problemy z rodzicami, utratę cennych dóbr osobistych (np. pieniędzy) czy problemy z rówieśnikami (Grzybowski, 2005: 246).

Podsumowując, oprócz daleko idących konsekwencji zdrowotnych, psychicznych czy ekonomicznych związanych z wczesną intoksykacją alkoholową, niebaga- 
telne znaczenie mają również restrykcje społeczne. Jak zostało wspomniane powyżej, wielu adolescentów zażywających alkohol doświadczyło nieprzyjemnych skutków społecznych, a sam brak kontroli nad ilością spożywanego alkoholu, który doprowadził do stanu upojenia alkoholowego, spowodował także, że niektóre osoby zostały zatrzymane $\mathrm{w}$ izbie wytrzeźwień czy nawet dopuściły się popełnienia przestępstwa (np. zabójstwa, kradzieży mienia, uszkodzenia ciała innej osoby itp.) (Grzybowski, 2005: 246), w związku z czym wachlarz konsekwencji społecznych wynikających $\mathrm{z}$ braku kontroli w spożywaniu alkoholu jest szeroki, a najdotkliwszą konsekwencją, jaką może ponieść sama jednostka, jest w dłuższej perspektywie czasowej uzależnienie od alkoholu.

\section{Mechanizmy uzależnienia}

Alkohol w sposób istotny wpływa na funkcjonowanie uzależnionej jednostki w obszarze emocjonalnym i umysłowym, oddziałując także na jej system Ja. Po długotrwałej intoksykacji chemicznej dochodzi do utworzenia się mechanizmów podtrzymujących chorobę, a także pozwalających jej się rozwijać - mowa o mechanizmie nałogowej regulacji emocji, iluzji i zaprzeczenia, dezintegracji Ja (Mellibruda, Sobolewska-Mellibruda, 2006: 105-124). Są to mechanizmy, na których opiera się nurt terapeutyczny polskiego lecznictwa odwykowego i które nie korelują bezpośrednio z traumatycznymi doświadczeniami z okresu dzieciństwa ${ }^{10}$. Są one wywoływane przez przykre stany emocjonalne oraz trudne sytuacje i prowadzą do autodestrukcji osoby chorej na poziomie biologicznym i psychicznym (Mellibruda, Sobolewska-Mellibruda, 2006: 105).

Nałogowa regulacja emocji powstaje jako pierwszy mechanizm i tworzy się już w stadium przedalkoholowym, w którym spożywanie alkoholu motywowane jest głównie społecznie (Cierpiałkowska, Ziarko, 2010: 72), jednak stopniowo zaciera się granica pomiędzy piciem towarzyskim a wyuczeniem reakcji picia na bodźce stresowe. Celem mechanizmu nałogowej regulacji emocji jest uśmierzenie nieprzyjemnych stanów emocjonalnych, by otrzymać natychmiastową gratyfikację w postaci przyjemności. Z biegiem czasu jednostka izoluje się od świata rzeczywistego, a niemal każdy stan emocjonalny przekształca się w silne pragnienie alkoholowe. Wszelkie procesy psychiczne podlegają wspomnianemu mechanizmowi, którego

${ }^{10}$ B. Włodawiec, Koncepcja psychologicznych mechanizmów uzależnienia Jerzego Mellibrudy; http://www.psychologia.net.pl/artykul.php?level=342 (dostęp: 01.04 .2014 r.). 
fundamentalnym podłożem działania jest psychofarmakologiczny wpływ alkoholu (Mellibruda, Sobolewska-Mellibruda, 2006: 117). W konsekwencji, dochodzi do zaburzenia funkcjonowania jednostki na poziomie psychofizjologicznym, gdzie procesy psychiczne i biologiczne, jako równorzędne i współwystępujące, są regulowane na poziomie intoksykacji alkoholowej (Mellibruda, Sobolewska-Mellibruda, 2006: 117-118).

Każda osoba używa myślenia magiczno-życzeniowego. Jest to proces psychiczny, który nie niesie ze sobą żadnych konsekwencji, jeśli występuje $\mathrm{w}$ formie przejściowej. U osoby uzależnionej, na skutek poczucia bezradności w odniesieniu do braku kontroli nad ilością spożywanego alkoholu i związanych z tym pragnień alkoholowych dochodzi do wzmacniania myślenia magiczno-życzeniowego, determinującego rozwój choroby i będącego fundamentalną częścią mechanizmu iluzji i zaprzeczania. Prowadzi to do powstawania wyidealizowanych i subiektywnych spostrzeżeń związanych $\mathrm{z}$ alkoholem. Stają się one zniekształcone i nie odzwierciedlają rzeczywistej wagi problemu uzależnionego. Pojawia się alekstymia, czyli niezdolność do rozpoznawania własnych stanów emocjonalnych, normalnie regulowanych przez procesy poznawcze, czego skutkiem jest przeobrażenie ich w pragnienia alkoholowe. Jednocześnie podczas stanów obiektywnej świadomości sytuacji problemowej, u jednostki nasilają się nieprzyjemne uczucia (smutek, żal itp.), które natychmiastowo przeobrażają się we wspomniane pragnienie alkoholowe (Mellibruda, Sobolewska-Mellibruda, 2006: 119-120).

Wymienione powyżej mechanizmy dezintegrują procesy psychiczne w systemie Ja jednostki, co skutkuje powstaniem mechanizmu rozpraszania i rozdwajania Ja. Prowadzi on do zaburzenia w obrębie organizacji funkcjonowania Ja, jak również naruszenia treści i struktury Ja, w wyniku czego powstają dwie przeciwstawne wersje jednej osoby (rozdwojenie Ja). Pierwsza, biegunowa wersja ujawnia się podczas intoksykacji alkoholowej - wówczas chory ma poczucie sprawstwa i mocy, subiektywnie ocenia realia zewnętrzne, nie dostrzegając własnego problemu, toteż nie zauważa powodu podjęcia leczenia. Druga, skrajna wersja własnej osoby ujawnia się podczas stanów trzeźwienia alkoholika. Wówczas bariera mechanizmów obronnych na moment zostaje złamana, dociera do świadomości uzależnionego powaga jego problemu, przy jednoczesnym odczuwaniu wstydu i winy ${ }^{11}$. Obydwa bieguny tworzą zamknięte koło choroby, pozwalając jej trwać przy jednoczesnym pogłębianiu się problemów uzależnionego.

${ }^{11}$ B. Włodawiec, op. cit. 
Towarzyszące alkoholikowi nieustanne stany upojenia alkoholowego i wiążąca się z tym alekstymia i utracona umiejętność sterowania własnymi procesami poznawczymi w aspekcie identyfikacji własnych stanów emocjonalnych, prowadzą do pojawienia się stanów zmienionej świadomości i rozpraszania granic Ja. Jak pisze Jerzy Mellibruda, „oznacza to istotne osłabienie spoistości i integracji struktury Ja w całym funkcjonowaniu osoby uzależnionej" (Mellibruda, Sobolewska-Mellibruda, 2006: 122).

Scharakteryzowane powyżej dwa procesy, wchodzące w skład mechanizmu rozpraszania i rozdwajania Ja, w ostateczności dezintegrują w sposób znaczący tożsamość jednostki, prowadząc do jej wydrążenia. Uzależniony nie potrafi określić własnej osobowości i sprecyzować, kim jest. Stan ten prowadzi do poczucia pustki i bezsensu życia przy równoczesnej utracie dotychczasowego systemu wartości i zasad moralnych. W rezultacie utrudnia to podejmowanie konsekwentnych i adekwatnych decyzji oraz zobowiązań.

Opisane wyżej trzy mechanizmy obronne, wykształcone w procesie długotrwałego i destrukcyjnego zażywania substancji psychoaktywnej, wzajemnie się uzupełniają, tworząc zwarty mur odgradzający alkoholika od świata zewnętrznego i jednocześnie determinujący rozwój choroby alkoholowej. Możliwość zburzenia owych destrukcyjnych mechanizmów psychologicznych występuje jedynie wówczas, gdy pojawi się silny impuls z zewnątrz, konfrontujący jednostkę z jej problemem (dla niektórych jest to utrata pracy, dla innych dezaprobata społeczna), prowadząc jednocześnie do podjęcia przez uzależnionego długoterminowego i często wieloaspektowego leczenia.

\section{Tradycyjne sposoby pomocy}

Współcześnie istnieje wiele form pomocy osobom uzależnionym od alkoholu i ich rodzinom. Można je podzielić na dwa główne style pomagania: pierwszy - profesjonalny, charakteryzuje się oddziaływaniami strukturalizowanymi podejmowanymi przez profesjonalistów, którzy wpływają na jednostkę technikami psychologicznymi bądź środkami farmakologicznymi. Drugi styl - nieprofesjonalny, tworzą szeroko pojmowane grupy samopomocowe, powstałe na początku XX wieku.

W Polsce obydwa style pomagania opierają się na Jellinkowskiej koncepcji alkoholizmu jako choroby nieuleczalnej i przewlekłej, oddziałującej na ośrodkowy system nerwowy chorego, powodującej w nim biochemiczne zmiany uniemożliwiające uzależnionemu powrót do kontrolowanej konsumpcji alkoholu (Cierpiał- 
kowska, Ziarko, 2010: 334-335). W związku z tym, celem terapii będzie abstynencja i jej utrzymywanie w czasie.

Istnieje także inne podejście, nieprzyjęte i nierozpowszechnione w Polsce, a oparte na gruncie psychologii behawioralnej, interpretującej chorobę alkoholową jako „nieprzystosowawczy bądź dezadaptacyjny wzorzec zachowania (nawyk), który powstał w wyniku uczenia się, zgodnie z zasadami warunkowania klasycznego, instrumentalnego czy modelowania" (Cierpiałkowska, Ziarko, 2010: 290-291). Zgodnie z tym modelem, interpretując go w sposób, w jaki został pokrótce zacytowany, w wyniku terapii awersyjnej oddziałującej techniką desensytyzacji lub metodą wygaszania (Cierpiałkowska, Ziarko, 2010: 291-292) możliwy jest powrót osoby pijącej problemowo do kontrolowanej konsumpcji alkoholu.

\section{Detoksykacja i farmakoterapia}

Detoksykacja stanowi pierwszy etap leczenia osób uzależnionych, a jej celem jest usunięcie z organizmu substancji psychoaktywnej obecnej po długiej intoksykacji alkoholowej, z zamiarem zminimalizowania objawów odstawienia. Detoksykacja może być przeprowadzona zarówno w domu, jak i w warunkach szpitalnych, w zależności od nasilenia objawów zespołu odstawiennego. Nie powinna być jednak stosowana jako samodzielna metoda lecznicza, lecz należy ją oprzeć na późniejszym długoterminowym leczeniu, ponieważ sama w sobie jest mało skuteczna i prawdopodobieństwo, że uzależniony znowu powróci do nałogu, jest tak duże jak u osób, które nigdy nie uczestniczyły w takich programach (Zaworska-Nikoniuk, 2001).

Farmakoterapia w leczeniu uzależnienia od alkoholu jest rzadko stosowaną formą terapii, a używana samodzielnie - jest także nieskuteczna. Stosuje się ją głównie jako środek pomocny w długoterminowym leczeniu, który ma na celu uwarunkowanie odczuć awersyjnych wobec spożycia alkoholu. Najbardziej popularnym lekiem jest disulfiram, znany jako anticol, który hamuje wydzielanie enzymu odpowiedzialnego za rozpad aldehydu octowego we krwi, w wyniku czego dokonują się zmiany w metabolizmie alkoholu (Cierpiałkowska, Ziarko, 2010: 315). Samoistna farmakoterapia, czerpiąc $z$ psychologii behawioralnej, opiera się na gruncie warunkowania instrumentalnego. Jednak problem uzależnienia ściśle powiązany jest z problemami intrapsychicznymi jednostki, na które wpływa wiele różnych czynników, w związku z czym, obok farmakoterapii, najczęściej stosuje się także, jako skuteczne powiązanie, długoterminowe leczenie psychoterapeutyczne bądź w ramach grup samopomocowych. 
Ostatnimi czasy większym zastosowaniem cieszą się leki, które pomagają trzeźwiejącemu już alkoholikowi zwalczać głód alkoholowy (naltrekson), oraz te umniejszające skutki w sferze psychicznej i fizycznej występujące w zespole abstynencyjnym (Cierpiałkowska, Ziarko, 2010: 315).

\section{Interwencja kryzysowa według Vernona E. Johnsona}

Jednorazowym, a równocześnie często długoterminowym w skutkach stylem pomocy osobie uzależnionej od alkoholu jest interwencja kryzysowa (koncepcja Vernona E. Johnsona), która ma miejsce, gdy uzależniony jest w fazie prekontemplacji (Cierpiałkowska, Ziarko, 2010: 301-302), i której celem jest przyspieszenie kryzysu i konfrontacja alkoholika z rzeczywistością w celu przełamania jego mechanizmów obronnych i zachęcenia go do podjęcia długoterminowego leczenia. W interwencji biorą udział najbliższe osoby chorego, które bezpośrednio doświadczyły skutków jego choroby. Podczas trwania spotkania informują uzależnionego o faktach $z$ jego życia, które przysporzyły im zmartwień, a były następstwem jego uzależnienia. Informuje się, zazwyczaj z dużą ilością detali, o sytuacji zaistniałej, jednak nie stosuje się żadnych wymówek ani pretensji, z którymi alkoholik mógłby dyskutować i wzmacniać tym samym mechanizmy iluzji i zaprzeczania. Po pozytywnie odbytej interwencji, gdy chory zdecyduje się podjąć leczenie, od razu musi być przygotowany plan terapeutyczny (tudzież często placówki lecznicze), by ten mógł podjąć natychmiastową terapię. Jest to bardzo istotne, ponieważ czekając na podjęcie leczenia, alkoholik mógłby na nowo zacząć pić i wszelkie mechanizmy obronne mogłyby ponownie objąć kontrolę nad jego funkcjonowaniem (Sztander, 1997).

\section{Ruch Anonimowych Alkoholików}

Grupa samopomocowa Anonimowych Alkoholików powstała w roku 1935 w Stanach Zjednoczonych na gruncie osobistych doświadczeń uzależnionego od alkoholu Billa W., jej założyciela (Zaworska-Nikoniuk, 2001). Idea AA szybko rozprzestrzeniła się na pozostałe rejony świata, w tym kraje europejskie.

W spotkaniach mogą brać udział wszyscy uzależnieni od alkoholu, a jedynym warunkiem i równocześnie celem takiego uczestnictwa jest zachowanie trzeźwości. Metody pracy grupy opierają się na szczegółowej analizie dwunastu kroków Anonimowych Alkoholików, odnoszonych do osobistych doświadczeń zgromadzonych. 
Wspomniane kroki zawierają treści, które skutecznie oddziałują na mechanizmy obronne uzależnionego, uczą go pokory, a co najważniejsze - uzmysławiają jego bezsilność w stosunku do alkoholu. Spotkania w ramach grupy AA mają silne oddziaływanie terapeutyczne i są bardzo skuteczne ze względu na wspólnotę problemów łączących wszystkich uczestników oraz poczucie jedności i przynależności grupowej.

\section{Psychoterapia integracyjna leczenia uzależnienia od alkoholu}

Indywidualna psychoterapia uzależnienia od alkoholu powstała na gruncie doświadczeń Jerzego Mellibrudy na oddziale odwykowym Instytutu Psychiatrii i Neurologii $\mathrm{w}$ Warszawie, a także podczas stażów zagranicznych realizowanych przez tego badacza w Stanach Zjednoczonych Ameryki (Cierpiałkowska, Ziarko, 2010: 312). Opiera się ona głównie na uznaniu przez pacjenta faktu własnego uzależnienia, identyfikacji mechanizmów uzależnienia oraz gruntownej pracy nad ich zwalczaniem i kreowaniem nowych wzorców zachowania kompensujących brak alkoholu i zapobiegających wystąpieniu głodu alkoholowego.

Podsumowując, dostępna jest szeroka gama propozycji pomocowych dla osób uzależnionych od alkoholu: zaczynając od interwencji kryzysowej według Vernona E. Johnsona, poprzez detoksykację, farmakoterapię i grupy samopomocowe, kończąc na terapii indywidualnej ukierunkowanej na relację z pacjentem $\mathrm{w}$ celu podtrzymania jego zdrowienia. Podobnie jak wspomniane trzy aspekty przyczyn uzależnienia od alkoholu, z których żadne samodzielnie nie determinuje pojawienia się choroby, tak też w lecznictwie odwykowym najbardziej skuteczne okazują się wieloaspektowe formy pomocy uderzające jednocześnie w czynniki fizjologiczne (detoksykacja, rzadziej farmakoterapia), struktury psychiczne (indywidualna terapia) i czynniki środowiskowe (grupy samopomocowe).

\section{Teoretyczne podstawy picia kontrolowanego}

Termin „picie kontrolowane” został wprowadzony przez studentów Uniwersytetu Kalifornijskiego - Marka i Lindę Sobell - w roku 1970. Uznawali oni alkoholizm nie za szeroko pojętą chorobę, ale za „jedno z wielu zaburzeń zachowania” (Peele, 1983: 41). Przeprowadzili w Szpitalu Patton State w Kalifornii badania ukierunkowane na osiągnięcie różnych celów u osób uzależnionych od alkoholu: całkowitej abstynencji lub kontrolowanego spożywania alkoholu. Według ich danych, osoby 
pijące w sposób umiarkowany funkcjonowały lepiej aniżeli te, które miały zachować abstynencję. Osoby pijące umiarkowanie funkcjonowały dobrze przez 160 ze 183 dni obserwacji, z kolei osoby mające utrzymać abstynencję - jedynie przez 80 dni (Peele, 1983). Idea Sobellów kłóciła się z Jellinkowską teorią alkoholizmu jako choroby nieuleczalnej. Ich podejście wywołało duże oburzenie w niektórych kręgach praktyków i teoretyków, czego skutkiem było napisanie artykułu przez Mary Pendery, Irvinga Maltzmana i L. Jolyona Wesat, w którym krytykowali oni podejście oraz badania przeprowadzone przez Sobellow, oskarżając ich jednocześnie o oszustwo (Peele, 1983).

Obecnie picie kontrolowane analizowane jest na bazie takich koncepcji teoretycznych, jak składniki poznawcze (przekonania, wspomnienia), zasady uczenia się, rodzaje osobowości, środowisko osoby pijącej oraz reguły i wartości kulturowe, a także mechanizmy mózgowe (Rosenberg, 2007: 46). Jako że sam trening uczenia umiejętności picia kontrolowanego opiera się na metodach behawioralno-poznawczych i społecznego uczenia się, tak też teorie interpretujące to założenie bazują głównie na tych koncepcjach psychologicznych.

Z perspektywy zasady uczenia się, tłumaczy się picie kontrolowane „jako funkcję zmiany bodźców dyskryminacyjnych" (Rosenberg, 2007: 46). W celu modelowania picia umiarkowanego, jednostka powinna unikać otoczenia, w którym picie nadmierne było nagradzane, a szukać takiego, w którym konsumpcja kontrolowana byłaby gratyfikująca. Należałoby także nauczyć jednostkę nowych sposobów radzenia sobie $\mathrm{z}$ trudnymi emocjami, wówczas nadmierna konsumpcja nie byłaby doświadczana nagradzająco. Mówi się także o relacji pomiędzy sygnałami bezpośrednio skojarzonymi, na drodze obserwacji i modelowania, z konsumpcją alkoholu a nadmiernym piciem. Unikając ekspozycji jednostki na owe sygnały, można osłabić występowanie wyuczonej reakcji organizmu na nie - głodu alkoholowego i tym samym relacji pomiędzy pewnymi bodźcami a piciem nadmiarowym - ucząc nowej reakcji - picia kontrolowanego (Rosenberg, 2007: 47).

Mówi się także o możliwości zmiany zachowań zautomatyzowanych (w tym wypadku picia nadmiarowego) i wykształceniu nowego nawyku odpowiadającego umiarkowanemu piciu. Wymaga to wiele wysiłku i treningu ze strony zainteresowanego, dopóki nowe zachowanie nie zostanie dostatecznie przećwiczone i zautomatyzowane (Rosenberg, 2007: 46-47). Niemniej jednak, podejście to traktuje bardzo mechanicznie i zewnątrzsterownie jednostkę, na której zachowania składa się przecież wiele czynników wynikających także z jej struktury osobowościowej i psychicznej. 
W tym aspekcie (struktury osobowościowej), psychoanalitycy uważają, że kluczem do nauczenia się picia kontrolowanego jest zaprzestanie używania alkoholu w celu regulacji i kontroli własnych stanów emocjonalnych (Rosenberg, 2007: 51). Koncepcja ta odnosi się do jednego $\mathrm{z}$ trzech mechanizmów uzależnienia opisanych przez Mellibrudę, czyli nałogowej regulacji emocji (Mellibruda, Sobolewska-Mellibruda, 2006: 116), będącej de facto fundamentem, na którym tworzone są dwa późniejsze mechanizmy uzależnienia. Pomija się przy tym konieczność przekonania jednostki do czynników gratyfikujących bądź awersyjnych związanych z piciem.

Problematykę tę porusza model poznawczy, ujmujący umiejętność picia kontrolowanego poprzez zmianę wyolbrzymionych, pozytywnych oczekiwań względem nadmiernego picia, na realistyczne oczekiwania dotyczące picia umiarkowanego oraz negatywne wobec skutków intoksykacji alkoholowej. Poznawczy model mówi o przejęciu tożsamości „osoby pijącej kontrolowanie” w celu nabycia umiejętności umiarkowanej konsumpcji alkoholu (Rosenberg, 2007: 48-49).

Warto także wspomnieć o poznawczo-behawioralnym modelu G. Alana Marlatta, ujmującym picie kontrolowane na gruncie interpretacji „zjawiska nawrotu w abstynencji” (Rosenberg, 2007: 49), a właściwie przekonań dotyczących „wpadki”. Rozumienie nawrotu nie w kryteriach porażki, ale lekcji, z której można wyciągnąć wnioski na przyszłość, umożliwia nabycie bądź utrwalanie umiejętności picia kontrolowanego. Takie pojmowanie możliwe jest dzięki wyuczeniu strategii umiejętnego radzenia sobie w sytuacji ryzyka i osiągnięciu kolejnych sukcesów we własnym kontrolowaniu spożywania alkoholu (Rosenberg, 2007: 49).

\section{Dotychczasowe wyniki badań}

Tematyka picia kontrolowanego w Polsce jest mało znana i dość kontrowersyjna, toteż pisząc o wynikach badań, należałoby odnieść się do tych prowadzonych w innych krajach.

Pierwsze badania zostały przeprowadzone przez Sobellów - autorów terapii picia kontrolowanego. Odbywały się one w Kalifornii w Szpitalu Patton State i wzbudziły wiele kontrowersji. Inicjatorzy chcieli przekonać się, co się stanie w momencie odmiennego traktowania, $w$ trakcie terapii, osób uzależnionych od alkoholu. Z podanych przez nich wyników, opierających się na rocznej i dwuletniej obserwacji pacjentów, wynikało, że lepiej funkcjonowali ci, którzy za cel obrali nabycie umiejętności picia kontrolowanego (Peele, 1983). 
Jak zostało już wspomniane powyżej, późniejsze badania, które przeprowadzili Sobellowie, obserwując grupę pacjentów w czasie od 19 do 24 miesięcy po ich terapii, wykazały, że dwudziestu spośród badanych, których celem była nauka picia umiarkowanego, funkcjonowało dobrze w 160 ze 183 dni. Z kolei jednostki, których celem było utrzymywanie abstynencji - jedynie przez 80 dni. Dodajmy, że termin „funkcjonowanie dobrze” jest definiowany jako niespożywanie alkoholu w ogóle bądź wypicie mniej niż równoważność sześciu uncji 43\% alkoholu (Peele, 1983). Sobellów koncepcja leczenia osób uzależnionych od alkoholu / nadużywających alkoholu jest sprzeczna $\mathrm{z}$ Jellinkowską teorią alkoholizmu uznawaną po dziś dzień, w związku z czym wywołała duże poruszenie w wielu środowiskach naukowych.

Ciekawe wyniki badań nad skutecznością terapii pacjentów chcących nauczyć się kontrolować własną konsumpcję alkoholu zostały przytoczone w artykule Alcoholism, Politics, and Bureaucracy. Peter Nathan (behawiorysta i były dyrektor Rutgers Center of Alcohol Studies) oraz Niaura, jego współpracownica, podsumowali czteroletnie badania opublikowane przez National Council on Alcoholism, w których wykazali, że mniej więcej $1 / 5 \mathrm{z}$ pacjentów uczących się podczas czteroletniej terapii pić w sposób kontrolowany oceniona została jako grupa osób pijących alkohol bezproblemowo, z czego 40\% z tych osób, według badaczy, to alkoholicy $\mathrm{w}$ stanie remisji $\mathrm{w}$ chorobie (Peele, 1992). Kontrowersyjne w swej istocie jest stwierdzenie, jakoby alkoholicy nauczyli się pić w sposób bezproblemowy.

Równie dyskusyjne oraz kontrowersyjne pięcioletnie i sześcioletnie badania zostały przeprowadzone przez Roberta G. Rychtarika, Davida W. Foya, Toma Scotta, Lindę Lokey i Donalda M. Prue. Badacze wykazali, że 18,4\% spośród badanych było chronicznymi alkoholikami, którzy nabyli umiejętność picia bezproblemowego i umiarkowanego (Peele, 1992).

W Szkocji oraz w Szwecji, w miastach Nordström i Berglund, zostały przeprowadzone długoterminowe badania kontrolne nad zachowaniem się osób uzależnionych od alkoholu. $\mathrm{Na}$ ich podstawie stwierdzono, że „alkoholicy wykazywali umiarkowanie w spożywaniu alkoholu w ciągu 16 do 20 lat obserwacji w trakcie badań" (Peele, 1992: 54). Ponadto, w artykule Alcoholism, Politics, and Bureaucracy uznano, że uzależnieni byli lepiej przygotowani do kontrolowania własnej konsumpcji alkoholu po zakończeniu badania. Kontrowersyjne wnioski wysunięto także w miastach Nordström i Berglund, gdzie na podstawie przeprowadzonych badań stwierdzono, że u wszystkich hospitalizowanych osób, zakwalifikowanych jako uzależnione od alkoholu, picie kontrolowane w o wiele mniejszym stopniu 
miało prowadzić do nawrotu choroby alkoholowej aniżeli abstynencja (Peele, 1992: 49-62).

Z tym twierdzeniem nie zgadzał się jednak George E. Vaillant, prowadzący długoterminowe badania w Ameryce, który wykazał, że alkoholicy próbujący kontrolować swoje picie są bardziej narażeni na nawrót choroby aniżeli ci utrzymujący abstynencję. Odmienność poglądów w dużej mierze zależna była od różnego definiowania terminu „alkoholik”. Vaillant kategoryzuje osobę jako uzależnioną, jeśli zdiagnozuje w ciągu ostatniego roku wystąpienie chociaż jednego symptomu uzależnienia (na przykład porannego picia), nawet jeśli przez pozostały okres osoba ta piła w sposób umiarkowany (Peele, 1992: 49-62).

Tematyką picia kontrolowanego szeroko interesowały się także inne kraje, w tym Niemcy oraz Szwajcaria, gdzie w warunkach ambulatoryjnych oraz stacjonarnych prowadzono na pacjentach długoterminową terapię ukierunkowaną na osiągnięcie różnych celów, w tym umiarkowanego spożywania alkoholu.

Szwajcarski Instytut ds. Alkoholizmu i Narkomanii (ISPA) przeprowadził siedmioletnie badania katamnestyczne na trzech grupach pacjentów z Forel Klinik: abstynentów, jednostek, które piły okazjonalnie, oraz osób spożywających alkohol w sposób problemowy. W dotychczasowych badaniach nad używaniem alkoholu powszechnie uznawano abstynencję za kryterium skuteczności terapii - w tym wypadku owym kryterium była jedynie poprawa jakości życia pacjentów. 24\% mężczyzn i 27\% kobiet spośród badanej grupy spożywało alkohol bez wystąpienia nawrotu choroby po wypisaniu z ośrodka leczniczego. Badacze uznali więc, że złamanie abstynencji nie musi zawsze oznaczać nawrot uzależnienia (Klingemann, 2006: 262).

Kolejne badania, prowadzone $\mathrm{w}$ Wattwil w Oddziale Psychosomatycznym (PSA) (jednak bez kontrolnych grup) w latach 1992-1993, wykazały, że po roku trzytygodniowej stacjonarnej terapii odsetek osób kwalifikujących się do zdefiniowania ich jako jednostki pijące w sposób kontrolowany („niespożywanie więcej niż 16 gram czystego alkoholu dziennie w przypadku kobiet i 24 gram w przypadku mężczyzn" [Klingemann, 2006: 263]), stanowił 9,3\%, z kolei u 13,6\% osób zauważono poprawę zachowań w związku z konsumpcją alkoholu (Klingemann, 2006: 263).

Kolejne badania, przeprowadzone przez Kaya Noschisa (psychologa), w których uczono grupę osób pić w sposób kontrolowany poprzez stosowanie „pamiętnika picia”, wykazały u 1/4 pacjentów poprawę zachowania względem spożywania alkoholu oraz poprawę atmosfery, tudzież kontaktu podczas terapii (Klingemann, 2006: 264). 
Inne badania, przeprowadzone w Szwajcarii, wykazały, że osoby obierające za cel terapii picie kontrolowane, w rok po jej zakończeniu konsumowały nieco więcej alkoholu aniżeli ci, którzy obrali za cel abstynencję, aczkolwiek ci pierwsi przez dłuższy czas kontrolowali własne spożycie alkoholu (Klingemann, 2006: 267).

Wyraźne dowody skuteczności terapii, której celem jest nabycie umiejętności umiarkowanej konsumpcji alkoholu, wykazały roczne badania prowadzone w Niemczech w roku 1999 przez Joachima Körkela. Badacz ten zdefiniował picie kontrolowane jako „zdyscyplinowane, planowane i limitowane spożywanie alkoholu” (Klingemann, 2006: 271), oparte na wcześniej ustalonych regułach bądź planie postępowania. Spośród 58 uczestników, w tym 21 kobiet i 32 mężczyzn, których średnia wieku wynosiła 48 lat, było 18 osób nadużywających alkoholu i 34 uzależnione. Sukces terapeutyczny odniosło 58\% osób, $8 \%$ utrzymywało abstynencję, z kolei u 25\% pacjentów stwierdzono 50\% redukcji pierwotnego spożycia alkoholu; ponadto $1 / 5$ badanych znacząco, bo prawie o połowę ograniczyła spożycie alkoholu (Klingemann, 2006: 272).

Na podstawie wyżej przytoczonych wyników badań można wysunąć wniosek o dużej skuteczności metody picia kontrolowanego jako celu terapeutycznego u jednostek będących w grupie ryzyka uzależnienia od alkoholu (ale nie uzależnionych) bądź młodych dorosłych, przed trzydziestym rokiem życia, dla których nabycie takiej umiejętności byłoby korzystne.

\section{Proponowany przebieg}

Analizując przytoczone na początku niniejszego artykułu dane statystyczne obrazujące zwiększający się odsetek adolescentów oraz młodych dorosłych coraz wcześniej i częściej spożywających alkohol, propozycja nauki picia kontrolowanego miałaby odwoływać się przede wszystkim do młodych dorosłych (osób powyżej osiemnastego roku życia), a jej celem byłoby zmniejszenie częstotliwości potencjalnego zażywania przez nich substancji psychoaktywnych i nabycie umiejętności kontrolowania konsumpcji alkoholu. Dzięki temu młodzi dorośli, hipotetycznie, mogliby uniknąć restrykcji społecznych, zdrowotnych i psychicznych związanych z intoksykacją chemiczną bądź nawet, w niektórych przypadkach, uniknąć uzależnienia. Proponowane metody nabycia umiejętności umiarkowanego spożywania alkoholu w przeważającej mierze opierają się na technikach z zakresu psychologii behawioralnej i technikach poznawczych. 
Pierwszy element pracy z pacjentem (poprzedzony przemyślanym i przeanalizowanym wyborem celu terapii, w tym wypadku - picia kontrolowanego) ma charakter edukacyjny - jest nim nabycie podstawowych informacji strukturalizujących wiedzę dotyczącą samego składu alkoholu etylowego, a także jego wpływu na organizm człowieka, oraz obopólne zdefiniowanie pojęcia „drink”. Tożsame rozumienie przez pacjenta i terapeutę pojęcia „drink” (dla pacjenta może oznaczać szklankę o pojemności $120 \mathrm{ml}$ wypełnioną w połowie wódką, dla terapeuty tylko $20 \mathrm{ml}$ wódki) stanowi formę prewencyjną służącą uniknięciu ewentualnych nieporozumień $\mathrm{w}$ trakcie trwania procesu terapeutycznego, mogących znacząco wpłynąć na jego przebieg (Miller, Muñoz, 2006).

Następnie weryfikuje się z pacjentem ilość spożywanego przez niego alkoholu oraz okoliczności, w jakich pije najczęściej, przy czym ustala się limity picia. Limity te dzieli się na dwie kategorie: limity regularnego picia, czyli „maksymalnej liczby drinków, które można wypić na co dzień” (Miller, Muñoz, 2006: 40), oraz limity okazjonalnego picia, czyli takiego, w którym poziom zawartości alkoholu we krwi nie przekracza poziomu maksymalnego obranego przez pacjenta. Przy ustalaniu limitów edukuje się pacjenta o sposobie analizowania wpływu alkoholu na własny organizm przy wykorzystaniu tabeli oceny zawartości alkoholu we krwi (Miller, Muñoz, 2006: 218).

Kolejnym krokiem w terapii jest wprowadzenie karty dziennego zapisu, w której pacjent oznacza datę, godzinę, rodzaj alkoholu, ilość oraz sytuację picia. Metoda rzetelnej samoobserwacji warunkuje dogłębną i stałą analizę spożywanego alkoholu w ciągu dnia i pozwala na autorefleksję umożliwiającą kontrolę nad ilością wypijanego alkoholu. Celem uzyskania gratyfikacji w formie widocznych postępów redukcji, a tym samym kontroli w spożywaniu alkoholu, jest karta podsumowania postępów, reasumująca całkowitą liczbę drinków w tygodniu, dni, w których utrzymany został regularny limit, największą liczbę drinków w tygodniu, najdłuższy czas picia w dniu, w którym alkohol był spożywany najdłużej, oraz szacunkowo najwyższą zawartości alkoholu we krwi w danym tygodniu. Jak się okazuje, metoda prowadzenia dzienniczka, bazująca na samoobserwacji, doprowadziła do ograniczenia picia średnio o jedną trzecią (Miller, Muñoz, 2006: 50-59).

Po wprowadzeniu pacjenta $\mathrm{w}$ problematykę alkoholu, jego stężenia we krwi i związanych z tym objawów somatycznych, a także metody analizy i samoobserwacji poprzez prowadzenie dzienniczków, następuje szereg sposobów umożliwiających skuteczniejszą kontrolę nad ilością spożywanego alkoholu. Z formy ogólnej, stosowanej dla każdego pacjenta (edukacja w kwestii alkoholu i jego wpływu na 
organizm oraz prowadzenie dzienniczków), William R. Miller i Ricardo F. Muñoz (psycholodzy) proponują szereg metod dostosowywanych indywidualnie dla każdej jednostki pod względem skuteczności oddziaływań (Miller, Muñoz, 2006: 60- 62).

Zwalnianie tempa (Miller, Muñoz, 2006: 63), czyli rozkładanie alkoholu w dłuższym przedziale czasowym, samo w sobie pozwala zmniejszyć ilość spożywanego alkoholu oraz ustalić własną tolerancję na alkohol. Zmniejszenie ilości spożywanego alkoholu warunkuje spadek tolerancji, co przy kolejnych sytuacjach konsumpcji powoduje wypijanie mniejszej ilości alkoholu (Miller, Muñoz, 2006: 63).

Jak podkreślają Miller i Muñoz, wszelkie nabyte umiejętności wspomagające proces nauki kontrolowania ilości spożywanego alkoholu nie będą skuteczne, jeśli jednostka nie nauczy się asertywności. Dlatego proponuje się pacjentowi szereg technik i metod skutecznego rezygnowania $\mathrm{z}$ dalszej konsumpcji, takich jak: niewerbalne okazywanie braku zainteresowania dalszym spożywaniem alkoholu („wystarczy [...] odmówić gestem” [Miller, Muñoz, 2006: 71]) bądź werbalną reakcję („dziękuję, ale potrzebuję trochę przerwy w piciu”). Autorzy proponują, na bazie desensytyzacji bodźca, przećwiczenie sytuacji, w której mogliby być narażeni na namowy ze strony znajomych do spożycia większej ilości alkoholu. Ponadto zalecają, by unikać otoczenia, które dokonuje intensywnej intoksykacji chemicznej, przynajmniej do czasu nauczenia się skutecznego kontrolowania spożywanej ilości alkoholu (Miller, Muñoz, 2006: 72).

Elementem, który powinien stale się pojawiać, by uskuteczniać proces nauki, jest gratyfikacja. Podkreślić jednak należy dość, zdaje się, oczywisty fakt, że formą nagradzania siebie za odmowę bądź umiarkowanie w piciu nie może być alkohol. Przy tym wymienić można dwa rodzaje nagród: materialne i psychiczne (Miller, Muñoz, 2006: 75).

$\mathrm{Na}$ tym etapie jednostka uczy się zachowań umożliwiających jej zwiększenie kontroli nad własnym postępowaniem w celu zmniejszenia ilości konsumowanego alkoholu w trakcie jego spożywania. Następnie podaje się szereg propozycji zachowań, które można stosować przed podjęciem decyzji o piciu (Miller, Muñoz, 2006: 89-111).

Jedną z takich propozycji jest weryfikacja czynników zewnętrznych wyzwalających chęć picia, czyli sytuacji i kontekstów społecznych, środowiskowych, psychologicznych, w których jednostka odczuwa silniejszą chęć konsumpcji (Miller, Muñoz, 2006: 89-102). Owa weryfikacja pełni rolę prewencyjną względem pojawienia się mechanizmu nałogowej regulacji emocji oraz służy nabyciu umiejętności unikania owych sytuacji oraz stosowania innych sposobów radzenia sobie w takim kontekście sytuacyjnym. Należy przy tym dokonać z pacjentem szczegółowej anali- 
zy i zaproponować alternatywne sposoby zachowania, tudzież radzenia z problematycznymi emocjami.

Następnie proponuje się zachowania alternatywne względem picia alkoholu. Jednym z nich jest życie „jak gdyby”, kiedy to jednostka ma dokonać próby udawania, w adekwatnej do tego sytuacji (np. podczas spotkania ze znajomymi, gdy pojawia się alkohol), że jest odurzona alkoholem, nie spożywając go w ogóle (Miller, Muñoz, 2006: 121-124). Metoda ta ma na celu udowodnienie klientowi możliwości cieszenia się różnymi sytuacjami bez konieczności intoksykacji.

Proponuje się także metody tak zwanego mądrego przemawiania do siebie (Miller, Muñoz, 2006: 129-133), czyli gruntownej analizy własnych stanów emocjonalnych przed wypiciem alkoholu oraz ogólnego, świadomego komunikowania z samym sobą. Można to uznać za metodę prewencyjną względem rozwijania się nałogowej regulacji emocji.

Dalej w tym kontekście zostają zaproponowane różne techniki relaksacyjne oraz metody skutecznego radzenia sobie ze stresem i depresją mogącymi być czynnikami determinującymi częściowo rozwój choroby alkoholowej (Miller, Muñoz, 2006: 141-168). Toteż ważne jest uczenie pacjenta technik samopomocy w sytuacjach stresowych, a także szeregu metod relaksacyjnych mogących stanowić alternatywę dla intoksykacji chemicznej.

Podsumowując, techniki, za pomocą których wdraża się pacjenta w nabycie umiejętności picia kontrolowanego, jakie proponują w swej książce Picie kontrolowane William R. Miller oraz Ricardo F. Muñoz (2006), można podzielić na trzy podstawowe części: podczas picia, przed konsumpcją i zamiast konsumpcji. Proponuje się szereg metod mogących pomóc jednostce w kontrolowaniu spożywania alkoholu, dzięki czemu nierzadko stanowią one formę profilaktyczną wobec pojawienia się picia problemowego. Terapia, której celem jest kontrolowane picie alkoholu, w dużej mierze uwzględnia indywidualność jednostki, jej możliwości i zasoby, by móc skutecznie dobrać techniki odpowiadające jej potrzebom i możliwościom w celu efektywnego zakończenia terapii i dostarczenia pacjentowi wzorca zachowań prewencyjnych względem wystąpienia problemu w konsumpcji alkoholu.

\section{Oczekiwane rezultaty wynikające z nauki picia kontrolowanego}

Głównym oczekiwanym rezultatem terapii ukierunkowanej na nabycie przez jednostkę umiejętności kontrolowania własnej konsumpcji alkoholu jest zmniejszenie ryzyka popadnięcia w chorobę alkoholową, a co za tym idzie - spadek liczby osób 
uzależnionych i poprawa jakości ich życia i stosunków społecznych. Propozycja ta jest uzasadniona $z$ punktu widzenia przytoczonych powyżej danych statystycznych dotyczących spożywania alkoholu w Polsce oraz liczby osób uzależnionych od alkoholu. Wiele osób, które nie są alkoholikami, lecz nadużywają alkoholu, chciałoby się nauczyć umiarkowania w jego konsumpcji, jednak polskie placówki, w przeważającej części, uznają dwie skrajności: albo pijesz jak dotychczas, albo zachowujesz całkowitą abstynencję. Dlatego wydaje się ważne wprowadzenie trzeciej drogi, alternatywy, która umożliwiłaby osobom z grupy ryzyka zatrzymać się na czas, by nie musiały wybierać pomiędzy dwoma skrajnymi biegunami.

\section{Podsumowanie}

Ze względu na patogenezę choroby alkoholowej oraz jej złożoność, korelującą ściśle z czynnikami środowiska społecznego, wydaje się bardzo mało prawdopodobne, by alkoholicy mogli nauczyć się spożywać alkohol w sposób kontrolowany. W związku z tym, picie kontrolowane, poszerzające zakres swych oddziaływań w niektórych krajach, może być nieskuteczne w grupie odniesienia osób uzależnionych w Polsce. Hipotetycznie można jednak założyć, że obszarem swego oddziaływania mogłoby objąć inną grupę osób, jaką stanowi młodzież. Wczesna inicjacja alkoholowa jest jednym z wielu czynników, które zwiększają „ryzyko zachowań problemowych" (Ostaszewski, 2005: 122). Tym samym, odwołując się do przytoczonych na samym początku niniejszego artykułu danych statystycznych dotyczących spożywania alkoholu przez polskich adolescentów, należałoby zwrócić uwage na wysoki odsetek osób pomiędzy 15 a 19 rokiem życia, które spożywają alkohol. Niektórzy autorzy uważają doświadczenia związane z używaniem środków psychoaktywnych za pewnego rodzaju prawidłowość pojawiającą się w okresie adolescencji. Mogą one „być dla młodzieży instrumentem osiągania pożądanych celów” (Ostaszewski, 2005: 14). Z tej perspektywy, nauka picia kontrolowanego, opierająca się na wielu koncepcjach i zapożyczająca od nich różnorodne techniki, hipotetycznie mogłaby pomóc młodym ludziom w osiągnięciu bezpiecznego i racjonalnego (czyli niepowodującego jakichkolwiek szkód zdrowotnych czy psychicznych) podchodzenia do kwestii spożywania alkoholu i samego eksperymentowania z nim. Może, hipotetycznie, podjęcie z młodzieżą tematu picia w sposób bezpieczny, uświadomienie, czym jest bezpieczne spożywanie alkoholu, oraz udzielenie profesjonalnej pomocy w nabywaniu umiejętności picia kontrolowanego osobom z grupy ryzyka uzależnienia zmniejszyłoby ilość osób borykających się z problemem uzależnienia od alkoholu? Pytanie pozostaje otwarte. 


\section{Literatura}

Cierpiałkowska L., Ziarko M. (2010). Psychologia uzależnień. Alkoholizm. Warszawa.

Grzybowski A. (2005). Alkoholizm - stale aktualny problem zdrowotny społeczeństwa polskiego. Aktywność samorządu w zakresie profilaktyki alkoholowej. „Nowiny Lekarskie” nr 2(74), s. 244- 250.

Jędrzejko M., Neroj A., Wojcieszek K.A., Kowalewska A. (2009). Teorie uzależnień od substancji psychoaktywnych. [W:] Współczesne teorie uzależnień od substancji psychoaktywnych. Red. M. Jędrzejko. Pułtusk - Warszawa, s. 77- 155.

Klingemann H. (2006). Picie kontrolowane: badania naukowe, doświadczenia płynące z praktyki oraz debata publiczna w Szwajcarii i Niemczech. „Alkoholizm i Narkomania”, nr 3, s. 259- 283.

Kozielecki J. (1995). Koncepcje psychologiczne człowieka. Warszawa.

Margasiński A. (2010). Rodzina alkoholowa z uzależnionym w leczeniu. Kraków.

Mellibruda J., Sobolewska-Mellibruda Z. (2006). Integracyjna psychoterapia uzależnień. Warszawa.

Miller W.R., Muñoz R.F. (2006). Picie kontrolowane. Sposoby na umiarkowanie, przeł. K. Mazurek. Warszawa.

Niewiadomska I., Sikorska-Głodowicz M. (2004). Alkohol. Lublin.

Ostaszewski K. (2005). Podstawy teoretyczne profilaktyki zachowań problemowych młodzieży. [W:] Diagnostyka, profilaktyka, socjoterapia $w$ teorii i praktyce pedagogicznej. Red. M. Deptuła. Bydgoszcz, s. 111- 137.

Peele S. (1992). Alcoholism, Politics, and Bureaucracy: The Consensus Against Controlled-Drinking Therapy in America. „Addictive Behaviors”, vol. 17, no 1, s. 49- 62.

Rosenberg H. (2007). Teoretyczne wyjaśnienia picia kontrolowanego. „Alkoholizm i Narkomania”, nr 1, s. $45-54$.

Seligman M.E.P., Walker E.F., Rosenhan D.L. (2003). Psychopatologia, przeł. J. Gilewicz, A. Wojciechowski. Poznań.

Stanton P. (1983). Through a Glass Darkly. Can Some Alcoholics Learn to Drink in Moderation? The Answer, at least in this Country, May Be More Political than Scientific. „Psychology Today” no 17, s. $38-42$.

Szmachowiec J., Kucharska-Mazur J., Szmachowiec A. (2011). Uzależnienie od alkoholu: od neurobiologii do nowoczesnej terapii. „Alkoholizm i Narkomania”, nr 2, s. 117- 123.

Sztander W. (1997). Poza kontrola. Warszawa.

Woronowicz B.T. (2008). Na zdrowie! Jak poradzić sobie z uzależnieniem od alkoholu. Poznań.

Woronowicz B.T. (2009). Uzależnienia. Geneza, terapia, powrót do zdrowia. Warszawa.

Zaworska-Nikoniuk D. (2001). Metody pomocy i samopomocy w uzależnieniach. Toruń.

Źródła internetowe:

Państwowa Agencja Rozwiązywania Problemów Alkoholowych, Statystyki; http://www.parpa.pl /index.php? option=com_content\&task=view\&id=155\&Itemid=16 (dostęp: 01.04.2014 r.).

Pisarska A., Monitorowanie zachowań ryzykownych młodzieży. Badania mokotowskie; http://www. ipin.edu.pl/wordpress/wp-content/uploads/2010/03/Raport_Badania_Mokotowskie.pdf (dostęp: 18.04.2014 r.).

Polski Przemysł Spirytusowy, Alkohol i społeczeństwo; http://www.pps.waw.pl/pliki/Newsletter/ Newsletter_1_2012.pdf (dostęp: 01.04.2014 r.). 
Ostaszewski K., Bobrowski K., Borucka A., Cybulska M., Kocoń K., Okulicz-Kozaryn K., Rapkiewicz M., Ekspertyza. Wplyw zmian wysokości stawki podatku akcyzowego od wyrobów spirytusowych w 2014 r. na dochody budżetu państwa; http://www.sobieski.org.pl/wp-content/uploads/Akcyza_ 2014_Instytut_Sobieskiego.pdf (dostęp: 22.04.2014 r.)

Urząd Statystyczny w Krakowie. Zdrowie dzieci i młodzieży w Polsce w 2009 r.; http://www.stat. gov.pl/cps/rde/xbcr/gus/zo_zdrowie_dzieci_mlodziezy_w_polsce_2009.pdf (dostęp: 01.04.2014 r.).

Włodawiec B., Koncepcja psychologicznych mechanizmów uzależnienia Jerzego Mellibrudy; http:// www.psychologia.net.pl/artykul.php?level=342 (dostęp: 01.04.2014 r.).

\section{Controlled Drinking - Helping Strategy Proposal for Young Adults}

\section{Summary}

In Poland, number of young people with alcohol experience is still growing. Primarily, they have problem with controlling the amount of alcohol consumed, and the early chemical intoxication is one of the many factors that increase the occurrence of these risky (reckless) behaviors. Therefore, in this article there will be presented statistics showing alcohol consumption by Poles, adolescents and young adults. Then, there will be shown wide-reaching consequences of excessive alcohol consumption by adolescents and young adults with reference mainly to describe the social consequences. Afterwards, there will be described both genetic causes of addiction as well as ones in relation to various psychological theories and concepts explaining the rise of alcoholism. Next, the mechanisms of addiction will be described with reference to traditional forms of aid used in some European countries and with reference to description of aid focused on the acquisition of skills of controlled drinking. Subsequently, there will be shown therapist's methods and techniques used to teach individuals to control their own alcohol consumption. They will be presented by reference to the origins of the method and its first creators in order to bring up the results of scientists who use this form of aid in practice and to the specificity of the different stages in their work with clients. Finally, the expected results arose from the controlled drinking study will be presented with regard mainly to young adults who, hypothetically, thanks to the acquisition of the ability to control their own consumption of alcohol, can not only avoid health, economic and social restrictions, but also alcohol addiction. 